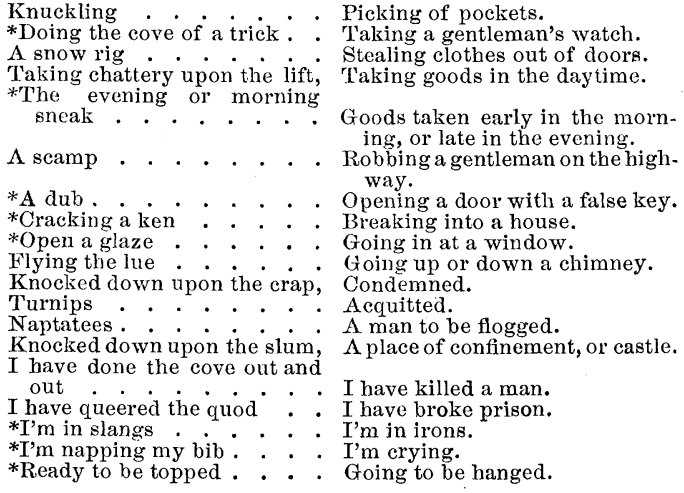

The same pamphlet adds the following:-

"The Oath at the Admission of a Flat into the Flash Society:-

"The oldest Flash cove taking the Flat by the hand, asks him if he desires to join the Flash Company. The Flat answers, Yes. The Flash cove (head man) bids him say thus:-

" I swear by - that to the Flash Company I will be true; never divulge their secrets, nor turn evidence against any of them; and if a brother is in distress, that I will hasten to relieve him, at the risk of my life and liberty; and if he suffers, endeavor to be revenged on the person or persons who were the means of bringing him to punishment.' After taking the above, or a similar oath, the Flat receives a pall; i.e. a companion, and they two are sent out upon some expedition.

"N.B. By the confession of Mount and Williams, it appears the Flash Company have spread themselves all over the continent, from Nova Scotia to the remotest parts of Georgia; that the principal seaport towns are their places of general rendezvous; and that the number of the society at present, are from about seventy to eighty, males and females. They have receivers in the principal towns of each State, who not only receive the stolen goods, but point out shops and houses for them to break into and plunder.

" Sometimes they swear by God, and sometimes by the Devil: when they use the name of God, they swear by the Old Cove, who knows all things; and when by the Devil, by the Cove of the Scarlet Ken!"

Henry Tufts mentions no such organization as this, directly or indirectly ; but the facility with which he found accomplices and places of concealment everywhere, from Maine to Virginia, would seem to render such a league very probable.

T. W. Higginson.

Cambridge, Mass.

\section{AN AVERAGE DAY IN CAMP AMONG THE SIOUX.}

On the day designated for a journey every one is astir, while the stars are still shining. Those who sleep late are wakened by the crackling of the leaping blaze. Shadowy forms are moving about the entrance to the lodge, and the boiling kettle warns the sleepy one that he had better be up and ready for breakfast. To slip out into the cool morning air, to dash the water over the face and hands, and dry them on the tall grass, is the work of a moment; and, with a little shaking together, every one is ready for the morning meal. This is portioned out by the wife, and each one silently eats his share. The baby still sleeps on its cradle-board, but the older children are relishing their broth with the vigor of young life. As each one finishes, he passes his dish to the matron, springs up, and leaves the tent. When the mother has eaten, she too goes out, and, with rapid steps and bent form, passes around the outside of the tent, pulling up the tent-pins used to hold the tent-cloth taught, and throwing down the poles which support the smoke-flaps. If there is an adult female companion, she takes out the round, slender sticks which fasten the tent-cloth together in front. The two women then fold back the cloth in plaits on each side, bringing it together in two long plaits at the back pole; and this is now tipped backward, and allowed to fall to the ground. The cloth is loosened from the upper part of the pole, and rapidly doubled up into a compact bundle. The baby, who has wakener and lain cooing to the rattle of blue beads dangling from the bow over its cradle-board, gives a shout as the sunlight falls in its face, and watches the quick motions of the mother throwing down the tent-poles, thus leaving the circle free of access. It is the leader's tent which first falls as a signal to all the others.

Meanwhile the boys are off with many a whoop, and snatch of song, gathering together the ponies. The men are busy looking after the wagons, or else sit in groups and discuss the journey and the routine of the intended visits, or attend to the packing of the gifts to be bestowed. All visitors are expected to bring presents to their hosts. The younger children run here and there, undisturbed in their play by the commotion. Soon the boys come riding in, swinging the ends of their lariats in wide circles, and driving before them a motley herd of ponies, some frisking and galloping, and others in a dogged trot, none following a path, or keeping a straight line, but spreading out on each side in the onward movement. As they come abreast with the dismantled tent, the women, without any break in their talk, make a dash at a pony, and generally capture him. The animal may, if he is good-natured, at once submit to be packed, two poles on each side, the packs containing the gala dress : bags filled with meat and corn are adjusted like 
panniers. Between the poles, which trail behind, a skin or blanket is fastened; and here the young children and the puppy have a comfortable time together as they journey. There are enough ponies for all the men and women to ride, and colts running along beside.

If wagons are to be used in travelling, the tent-poles are tied on each side of the wagonbox. The harness is dragged along by a woman, who slings the mass of straps and buckles on the pony's back, he giving a slight start as the load drops on him. The buckling is quickly done by the women, and the stores packed in the bottom of the wagon. Finally the kettle and coffee-pot are picked up; and nothing is leit of the camp but circles of trampled grass, each one with a pile of ashes in its centre.

The delight of being ' off' affects every one, the older people enjoying it sedately : the young men dash about up on the hills, where they stand silhouetted against the cloudless sky. Now and then they drop from their ponies, and lie flat on the ground, while the animal nibbles unconcernedly. The women ride with the stores in the bottom of the wagon, and the men on the seat, driving. It is hard, teeth-chattering work to travel in the bottom of a springless wagon, and no fun to ford a rapid river full of quicksands; for down will go one wheel, and the water come swirling in, wetting every thing and every body. At such times the bags of provisions are held high aloft in the hands : all else must take its chance. Those on the ponies fare better; for, with the feet on the horse's neck, all goes well, unless the little fellow gets into a very bad hole, and topples over into the water. Sometimes the men take off leggings and moccasins, roll them in a bundle, tie them on the head or back of the neck, and wade over, leaving the pony to follow. Such persons generally have time enough to lie down on the bank to dry off, and from their vantage-point watch the struggles of the loaded wagon as the men spring from their seat into the stream, and tug at the wheels to save the vehicle from sinking.

All day we ride over the prairie-trails, starting up the birds, seeing the flash of the antelope, or catching sight of the retreating wolf. If location serves, about three o'clock we camp, always near a stream and timber. It is the work of a few moments to set up the tents, while the men and boys scatter with the ponies. The young girls go laughing to the creek for water, the older women cut and gather the dry wood, and in less than an hour the thin blue smoke is curling through the tent-flaps, and the kettle hanging on its crotch-stick over the fire. Each bundle of bedding is thrown down in the place its owner is to occupy, and it will be untied and spread when needed.

There is a fascination in lying on the grass after a hard day's ride, and watching the settling of a camp. The old men gather in groups, and smoke the pipe. The young men lie at full length, resting on their elbows, their ornaments glistening in the sunlight as these gallants keep watch through the swaying grass of tents where coy maidens are on household cares intent. It is not unlikely that more than one youth is planning how he can best gain access to his sweetheart, and speak a few words to her when she goes for water to the creek in the early morning; and it is equally possible that similar thoughts are flitting through the girl's head. The creek or the spring is the trysting-place for lovers, but the chances for a word are hard to gain.

It is against etiquette for a young woman to speak to any man in public who is not a near relation; and such a one, by the law of the gentes, can never be a lover. But young hearts are stronger than society restrictions; and so when the girl, accompanied by her mother or aunt, goes for water in the early morning, she will sometimes drop behind her chaperone, and the young man, who has lain hid in the grass, darts forward, swiftly and silently, and secures the favored moment. Should the mother turn, he as instantly drops in the grass; while the girl demurely walks on, keeping her secret.

The small boys have already fallen into games, and are shooting arrows of barbed grass. From within the cone-shaped tents comes the sound of the chatter of the women, broken now and then by loud laughter. This might arise from the practical joking of the mother's brother. Such a relative is privileged in the home, and the source of many sports. While the women are cutting up the meat for the evening meal, and preparing the corn-cake, the young man, lounging in the shadows of the tent, has improvised a drum, captured his small nephew, and breaking into song, bids the little fellow dance for his supper. He obeys with a zest, his scalp-lock, and the flaps of his breechcloth, snapping to the tune. The little sister, having secured a premature bite from the mother, stands diligently eating, as she watches her brother's antics, stimulated by the mischief-loving uncle.

There are shiftless folk among Indians, persons who are always borrowing from their more forehanded relatives; but not all borrowers are of this class. A custom prevails concerning borrowing a kettle susceptible of easy misconstruc- 
tion by our own tidy housewives; that is, that it is expected, when a borrowed kettle is returned, that there will be a small portion of the food which has been cooked in the kettle remaining in the bottom of the pot. The language has a particular word to designate this remnant. Should this custom be disregarded by any one, that person would never be able to borrow again, as the owner must always know what was cooked in her kettle.

Great indignation was the result of the action of a white woman, who returned a scoured kettle. She meant to teach a lesson in cleanliness; but her act was much talked over, and interpreted as fresh evidence of the meanness of white folk !

Soon the savory odors give token that supper is ready. Dishes are set in the traditional places occupied by the members of the family, and the food ladled out, and portioned to each person. The little girl is sent out to call the men in. There is no formality about the family meal. If the father is a religious man, he may take a bit of his food, lift it up, and drop it in the fire ; the act is without ostentation, and apparently unobserved by the others. Sometimes the children take their supper together outside the tent. The mother seldom eats until all are fully served. She may join her children with her portion; or if she has female companions in the tent, they will draw together, and gossip over the meal. Every one falls to with zest, and the pot is generally emptied.

After eating, all lie down, stretching out in the tent, or going outside if the day is fine, and resting in the long slanting sunlight. As the air cools, a fire is kindled; and here grouped about the companionable blaze we watch the stars come out. Some persons doze, some discuss the journey, or recount reminiscences of former times: the women gather together and complete the story of the day; while the children chase the fireflies, or subside into drowsy listeners. Across the hum of voices is borne the song of a young man, who, hidden in the grass, lies on his back drumming on his breast as he sings. There are no urgent demands upon any one. The matron has no dishes or linen to wash, or scrubbing to do ; there is nothing to clear away after the evening meal: the single pot is emptied, and set to one side. No transitory fashions perplex the fancy of the maiden, no lessons to learn harass the child. The men talk or sing, unconscious of money making or losing, or questions in science or art. 'To the people, no great disasters are probable, no great successes possible. The stars above silently hold their secrets, the un- marred prairie tells no tales, and the silence of uninquisitive ignorance shuts down upon our little life.

To one thrust from the midst of civilization into so strange a camp-circle, the summer days hardly bring a realizing sense of the great estrangement between the two orders of society. It is only when the frozen calm of winter obliterates every touch of color and individuality of outline in the landscape that it becomes possible to gauge fully the mental poverty of aboriginal life. The cold nights when the tent freezes hard so that it sounds like a drum, and the frost lies thick on the bedrobes, make one dread to rise early; and the sun is often up before the fire is kindled, and the kettle bubbles with the morning meal. After looking to what comfort it is possible to give the ponies, and having gathered in the wood, the outdoor work of the day is over.

In winter the tent is made warmer by putting a lining around to half the height of the tentcloth, and by banking without and within, stuffing with grass the space between the lower edge of the tent-cloth and the ground to keep out the wind. This done, and with plenty of wood to feed the fire, one can be passably comfortable. During the day the women are busy making clothes, mending moccasins, or embroidering gala garments with porcupine quills or beads : the men, if not out trapping, are engaged in fashioning pipes and clubs, or shaping spoons on the ball of the foot. The winter is the season for story-telling, and many hours of the evening are spent in this enjoyment.

The cold season brings pleasures to the children, - snowballing, sliding down hill on blocks of ice, or standing on a flat stick and coasting swiftly, balancing with a pole. The glow on the faces of the little ones as they run in breathless from their sport to meet the welcome of the group within the tent, is about the only zest the days bring.

$$
\text { Alice C. Fletcher. }
$$

\section{THE CAROLINE ISLANDS.}

Micronesia, or the 'Little Islands,' is a fitting name given to that portion of the Pacific Ocean lying between $134^{\circ}$ and $177^{\circ}$ longitude east from Greenwich, and from $2^{\circ}$ south to $20^{\circ}$ north latitude. Within these boundaries it is estimated that there are not far from one thousand islands, divided into four groups, - the Gilbert, Marshall, Caroline, and Ladrone. 'The Ladrone Islands on the north, between $144^{\circ}$ and $146^{\circ}$ longitude, were discovered by Magellan 